\title{
Permanent anti-graffiti for artificial construction materials: lime mortar and brick
}

\author{
P.M. Carmona-Quiroga, M.T. Blanco-Varela \\ Eduardo Torroja Institute for Construction Science (IETcC-CSIC), Madrid, Spain \\ S. Martínez-Ramírez \\ Institute for the Structure of Matter (IEM-CSIC), Madrid, Spain
}

\begin{abstract}
The effectiveness of two permanent anti-graffiti treatments, a commercial fluoroalkyl siloxane and an organically modified silicate (Ormosil), in two artificial building materials, brick and lime mortar, was analyzed. The research was based on the assessment of the physical properties, cleaning efficiency and durability of the coated construction materials. The results showed that both treatments induced minimal chromatic variations in the materials surface. Ormosil was a better water repellent for its greater capacity to fill the pore systems that enhanced materials resistance to freeze-thaw cycles while lowering their water vapour permeability. Graffiti (alkyd spray paint) cleaning was satisfactory for the brick, after 4 cycles, particularly with the commercial anti-graffiti. On the other hand, lime mortar resisted only one cleaning episode, which removed not only the paint, but part of the material surface.
\end{abstract}

\section{INTRODUCTION}

The damage caused by the traditional agents of construction materials decay, namely water, air pollutants, biological agents and so on, is accentuated by direct human action in the form of graffiti and soiling. While graffiti can be found on nearly any surface, their effects - visual impact and deterioration - are especially pernicious in historic masonries: such as brick and stone walls.

Lime mortar, a traditional pointing and rendering material that fell into disuse when Portland cement started to be produced, is nowadays regaining attention thanks to the restoration of some of these historic masonry works (Maravelaki-Kalaitzaki et al. 2005, Myrin \& Balksten 2006, Pavía \& Caro 2006), and therefore it is susceptible, like other materials, to graffiti attacks.

Anti-graffiti coatings have been developed to protect the surface of construction materials by preventing paint from penetrating their pore systems or from adhering to the surface, since the removal of graffiti with traditional (chemical or mechanical) methods is not always successful and/or inevitably entails altering surface characteristics of the materials. These protective treatments at the same time that facilitate cleaning operations (with pressurized water, chemical products and so on) when applied to historic masonries must respect their aesthetic integrity (minimum changes in their gloss and colour) and not induce undesirable changes in superficial energy, permeability and so on.

This study aimed at assessing the effectiveness of two of these protective treatments a fluorinated commercial product (fluoralkyl siloxane) and an organically modified silicate (Ormosil), both known as permanent anti-graffiti, in two different materials, lime mortar and brick, which can be easily found in historic walls (studies in stones and cement with these anti-graffiti treatments have been published elsewhere (Carmona-Quiroga et al. 2010a)), since so many little research has been conducted to test the suitability of these new protective treatments in conservation of Cultural Heritage (Segalini et al. 2001, Di Gennaro et al. 2002, Di Gennaro et al. 2003, García \& Malaga 2012). 


\section{METHODOLOGY}

Lime mortar specimens measuring $70 \times 60 \times 10 \mathrm{~mm}$ were prepared with commercial lime mortar (Calhidro, Guipúzcoa, Spain) and a binder+sand/water ratio of 4.6/1 and cured until complete carbonatation in a chamber with $\mathrm{CO}_{2}$. An in-plant waterproofed brick (with methyl siliconate to avoid efflorescence; Hermanos Díaz Redondo, Toledo, Spain) was the second artificial building material selected for the present study. Two permanent anti-graffiti treatments: a commercial product (waterbased fluoroalkylsiloxane, Protectosil Antigraffiti by Degussa) and a organically modified silicate (Ormosil) (Oteo et al. 1999) were chosen.

Changes in construction materials porosity, saturation coefficient, water-vapour permeability, colour and gloss induced by the two anti-graffiti were determined as specified in CarmonaQuiroga et al. (2010a). Cleaning (spray paints) efficiency was assessed by repeating 4 times the procedure described in Carmona-Quiroga et al. (2010b). Durability tests which included up to 30 freeze-thaw cycles and 2000 hours of UVA radiation were also conducted. The photochemical stability after UV exposure was analyzed by FTIR. The treatments response to $\mathrm{SO}_{2}$-polluted atmosphere has been previously studied in Carmona-Quiroga et al. (2010c).

\section{RESULTS AND DISCUSSION}

\subsection{Physical and hydric characterization of the coated brick and lime mortar}

Some of the physical and hydric properties of the lime mortar and brick before and after being impregnated with the two anti-graffiti products are given in Table 1. Mercury intrusion porosimetry revealed that the fluorinated anti-graffiti had no effect on the total porosity (accessible to mercury) of both construction materials, whereas Ormosil, by filling the pores primarily with a diameter of under one micron, lowered their porosity by 11 (brick) to $21 \%$ (lime mortar). The water-vapour permeability of both materials declined accordingly by only 7 to $8 \%$ with the fluorinated product, while Ormosil lowered their permeability by 13 to $15 \%$ (Table 1).

Saturation (48 hours at atmospheric pressure) values were similar for both substrates before and after being coated with the commercial anti-graffiti (between 13 to $16 \mathrm{wt} . \%$ ). This finding is consistent with the null decline in their porosity accessible to mercury (Table 1). By contrast, in the Ormosil-coated samples, the amount of water freely absorbed by the materials declined very significantly (around 90\%).

The two anti-graffiti coatings darkened (denoted by $\mathrm{L}^{*}$ value) the brick surfaces slightly and generated weak yellowing ( $\mathrm{b}^{*}$ coordinate), with minor variations (almost unnoticeable: $\Delta \mathrm{E}^{*} \approx 5$, (Di Gennaro et al. 2002)) in the brick overall colour. In lime mortar, colour changes were not observed with the naked eye $\left(\Delta \mathrm{E}^{*}<<5\right)$. Surface gloss was slightly raised by the commercial anti-graffiti and insignificantly lowered by Ormosil in both building materials.

Table 1. Some physical and hydric properties of lime mortar and brick before (UT) and after being coated with two anti-graffiti (standard deviation).

\begin{tabular}{|c|c|c|c|c|c|c|}
\hline & UT lime mortar & Fluorinated & Ormosil & UT brick & Fluorinated & Ormosil \\
\hline Hg porosity & $38(2)$ & $38.5(0.4)$ & $30(1)$ & $32.9(0.4)$ & $31.8(0.6)$ & $29.4(2)$ \\
\hline$(\%) \quad \leq 1 \mu \mathrm{m}$ & $6.4(0.5)$ & $6(1)$ & $0.3(0.2)$ & $32(1)$ & $31.4(0.8)$ & $28(2)$ \\
\hline $\begin{array}{l}\text { Saturation coefficient } \\
(\% \text { mass })\end{array}$ & $14.9(0.3)$ & $12.6(0.6)$ & $1.4(0.2)$ & $15.2(0.6)$ & $15.9(0.3)$ & $1.3(0.6)$ \\
\hline $\begin{array}{l}\text { Decline in permeability } \\
(\%)\end{array}$ & $\wedge$ & $7(5)$ & $15(4)$ & $\wedge \wedge$ & $8(2)$ & $13(4)$ \\
\hline Colour $\quad L^{*}$ & $87(1)$ & $88.5(0.4)$ & $87.3(0.7)$ & $61.7(0.4)$ & $59.8(0.4)$ & $58.3(0.5)$ \\
\hline$a^{*}$ & $0.2(0.1)$ & $0.02(0.05)$ & $0.2(0.1)$ & $16.4(0.1)$ & $17.9(0.1)$ & $18.3(0.4)$ \\
\hline$b^{*}$ & $3.1(0.1)$ & $2.7(0.2)$ & $3(0)$ & $27.2(0.2)$ & $31.2(0.1)$ & $29.4(0.8)$ \\
\hline$\Delta \mathrm{E}^{*}$ & & $1.2(0.4)$ & $0.5(0.4)$ & & $4.7(0.2)$ & $4.4(0.8)$ \\
\hline Gloss units $\left(85^{\circ}\right)$ & $6(5)$ & $16(4)$ & $3(2)$ & $3.2(0.4)$ & $7.3(0.6)$ & $1.6(0.5)$ \\
\hline
\end{tabular}




\subsection{Cleaning efficiency}

Permanent anti-graffiti treatments should be durable enough to withstand numerous cleaning cycles. The lime mortar and brick coated with the two treatments were subjected to a total of 4 . After that, total colour variation of the surfaces was measured (Fig. 1). Lime mortar resisted only one cleaning episode, after that not only the paints were removed, but part of the treated material surface (the low energy barrier), turning the protection in ineffective. In brick, no traces of paint after 4 successive cleaning cycles were observed $\left(\Delta \mathrm{E}^{*}<5\right.$; Fig. 1$)$. The characteristics of the substrate, namely its scant roughness and prior, in-plant waterproofing, favoured these good results. Nonetheless, the post-cleaning chromatic values of untreated brick surfaces revealed the importance of the paint repellence of the two anti-graffiti treatments, particularly the commercial one, in achieving such effective cleaning.

Further to the measurements of the brick chromatic parameters, the elimination of the paints slightly darkened and yellowed the surfaces, the first in the specimens treated with Ormosil and the second in the ones impregnated with the commercial anti-graffiti.

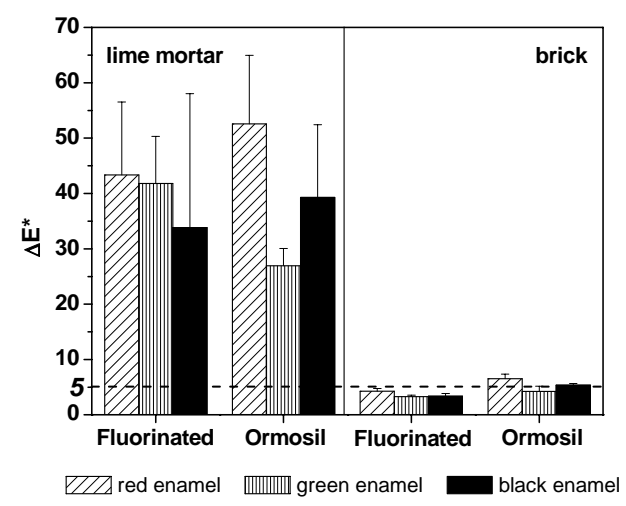

Figure 1. Total colour variation $\left(\Delta \mathrm{E}^{*}\right)$ of the anti-graffiti coated brick and lime mortar after 4 successive painting-cleaning cycles.

\subsection{Durability}

The results of the freeze-thaw cycles revealed that Ormosil improved brick and lime mortar resistance to frost by inducing a decline in their saturation coefficient (Fig.2a, c). Meanwhile, the fluorinated anti-graffiti accelerated their deterioration by obstructing the egress of water trapped in the pore systems during successive thawing episodes (Figs 2a, b, d).

Neither of the treatments exhibited decay after exposure to UV radiation (2000 hours) according to FTIR analysis.
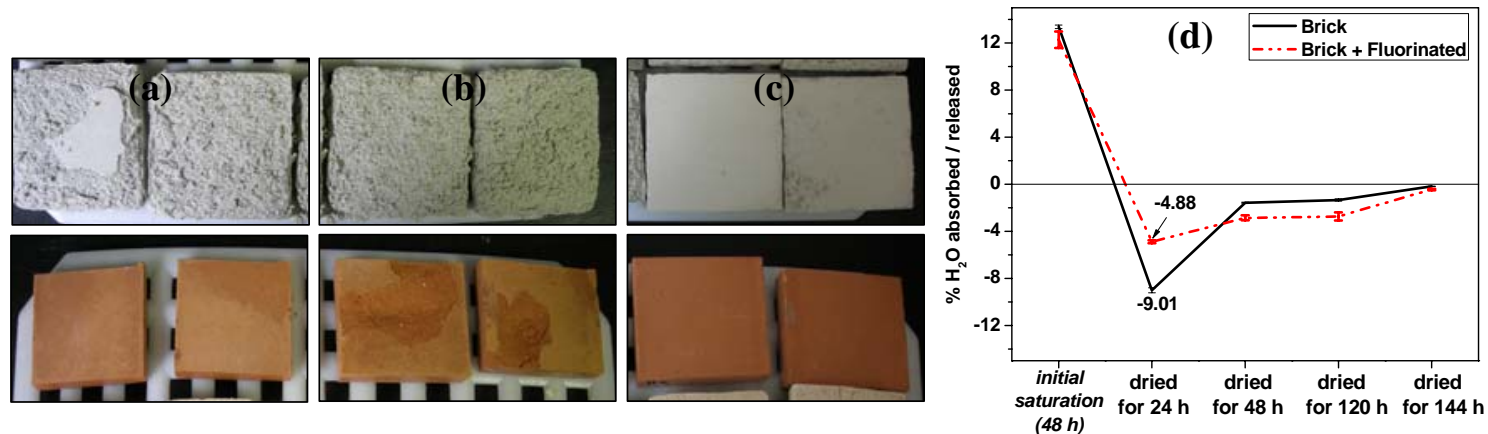

Figure 2: Pictures of lime mortar (above) and brick (below) uncoated (a); coated with the fluorinated antigraffiti (b) and with Ormosil (c) after 30 freeze-thaw cycles. (d) Water desorption of brick untreated and treated with the fluorinated anti-graffiti. 


\section{CONCLUSIONS}

The different behaviour of the two permanent anti-graffiti chosen, a commercial fluoralkyl siloxane and an organically modified silicate, reaffirms the necessity of their individualized testing prior to applying to historic masonry.

In bricks, cleaning was more satisfactory with the fluorinated treatment than with Ormosil; however the latter exhibited higher performance as a water repellent due to its capacity to fill the material pores, which translated into an improvement of brick resistance to frost and a high decline in material permeability. The fluorinated anti-graffiti, on the contrary, accelerated the weathering in freeze-thaw cycles by obstructing the egress of water trapped in the pore system.

In lime mortar cleaning was totally ineffective, with both treatments, due to its soft nature unable to withstand the several cleaning-painting cycles conducted. As it happened in brick, the Ormosil improved material resistance to frost and the fluorinated treatment worsened.

In spite of some of these drawbacks, both anti-graffiti seemed to fulfill the requirements of "invisibility" (minimum changes in gloss and colour) and "stability" (UV radiation) needed to be applied to built Heritage.

\section{ACKNOWLEDGEMENTS}

Funding from the Spanish Ministry of Education and Science (Project CONSOLIDER CSD2007-00058) and the Regional Government of Madrid (Geomaterials Programme) is gratefully acknowledged.

\section{REFERENCES}

Carmona-Quiroga, P. M., Martínez-Ramírez, S., Sobrados, I., Blanco-Varela, M.T. 2010a. Interaction between two anti-graffiti treatments and cement mortar (paste). Cement and Concrete Research 40(5): 723-730.

Carmona-Quiroga, P. M., Martínez-Ramírez, S., Sánchez-Cortés, S., Oujja, M., Castillejo, M., BlancoVarela, M.T. 2010b. Effectiveness of antigraffiti treatments in connection with penetration depth determined by different techniques. Journal of Cultural Heritage 11(3): 297-303.

Carmona-Quiroga, P. M., Panas, I., Svensson, J-E., Johansson, L-G., Blanco-Varela, M.T., MartínezRamírez, S. 2010c. Protective performances of two anti-graffiti treatments towards sulfite and sulfate formation in SO2 polluted model environment. Applied Surface Science 257(3): 852-856.

Di Gennaro, F., Ferrari, A., Pagella, C., Cervellati, G. 2002. Petrographic study on efectiveness of antigraffiti protective tratment (Part 1-Stony materials of carbonatic composition ). Pitture e Vernici, European Coatings 78(17): 23-31.

Di Gennaro, F., Ferrari, A., Pagella, C., Cervellati, G. 2003. Petrographic study on efectiveness of atigraffiti protective treatment. (Part 2-Stony materials of silicate composition). Pitture e Vernici, European Coatings 79(6): 7-14.

García, O. \& Malaga, K. 2012. Definition of the procedure to determine the suitability and durability of an anti-graffiti product for application on cultural heritage porous materials. Journal of Cultural Heritage 13(1): 77-82.

Maravelaki-Kalaitzaki, P., Bakolas, A., Karatasios, I., Kilikoglou, V. 2005. Hydraulic lime mortars for the restoration of historic masonry in Crete. Cement and Concrete Research 35(8): 1577-1586.

Myrin, M. \& Balksten, K. 2006. Lime-based repair mortars - influence by surface working methods on behaviour and durability of mortar. In R. Fort, M. Álvarez de Buergo, M. Gómez-Heras \& C. Vázquez-Calvo, Madrid (eds), Heritage, Weathering and Conservation (HWC); Proc. intern. symp., Madrid, 21-24 June 2006. London: Taylor \& Francis.

Oteo, J. L., Rubio, J., Rubio, F. (CSIC). 1999. Materiales termohíbridos inorgánico-orgánicos de baja densidad y su procedimiento de obtención. Spanish patent No. 9901977.

Pavía, S. \& Caro, S. 2006. Lime mortars for masonry repair: Analytical science and laboratory testing versus practical experience. In J. Delgado Rodrigues \& J. M. Mimoso (eds), Theory and Practice in Conservation- a tribute to Cesare Brandi; Proc. intern. semin., Lisbon, 4-5 May 2006. Lisbon: LNEC.

Segalini, S. D. C., A., De Pinto, G., Pegoraro, M. 2001. Antigraffiti removers and antigraffiti coatings. Pitture e Vernici, European Coatings 77(7): 7-15. 